\title{
PROFILE: ILAN VOLKOV
}

As chief conductor of the Iceland Symphony Orchestra and Principal Guest Conductor of the BBC Scottish Symphony Orchestra, Ilan Volkov is a significant presence in the mainstream classical world. As an improvising musician and curator of Tectonics, a three-day festival of contemporary music he founded in 2012, he is also deeply immersed in more avant-garde currents. Tectonics Festival - now held in Reykjavík, Glasgow, New York, Tel Aviv and Australia - aims to explore the hinterland between experimental and orchestral music. This breadth of activity reflects Volkov's determination to cross musical

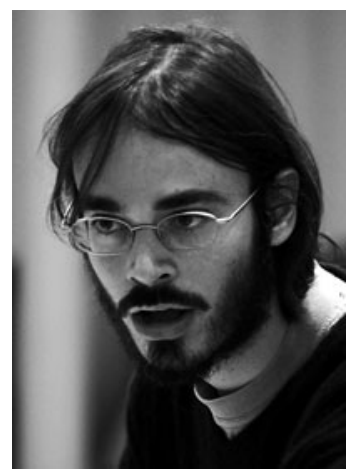

Ivan Volkov photographed by

Simon Butterworth genres and keep alive the creative spirit and sense of artistic adventure that shaped modernist compositions of the last century.

Q. 'New', 'contemporary', 'modern': what attracts you to 'this' music? A. I started getting into classical contemporary music quite early. I was hooked on a Stravinsky LP box my father had, and that led to buying a Wozzeck recording which blew my mind! This led to studying composition and listening to tons of stuff. I don't know anymore what 'attracts' me to it all - I love it and enjoy it. What really opened things up for me was being in London between 1993 and 1997 and listening to lots of improv concerts and non-classical new music. All these interests led to the creation of Tectonics Festival.

Q. What does 2014/15 hold for you and for Tectonics?

A. 2014 has been very busy: four Tectonics festivals in Adelaide with Adelaide Symphony Orchestra as part of Adelaide Festival, in Glasgow with BBC Scottish Symphony Orchestra, in New York at Issue Project Room, and in Reykjavik for the third time with Iceland Symphony Orchestra in collaboration with Harpa concert hall. October 2014 will see the second Tel-Aviv event, which will happen in three different venues. Then again in Reykjavik and Glasgow next Spring.

Q. Who are your new music heroes?

A. Too many to list really ... but I will have a go.

Firstly, Bruno Maderna - a fantastic composer and conductor. His live recordings of classical repertoire are stunning, for example Schubert's Great Symphony. There is a film by Luc Ferrari in which Maderna is conducting Varèse's Déserts which I find incredibly powerful and exciting. John Tilbury is one of my favourite people - such a lovely person and I love his piano playing, whether he plays Feldman or Skempton or improvises. His touch on the piano is just astounding. He played Palais de Mari [Feldman] at the first Tectonics Festival in 2012 - it was so beautiful. I will never forget that performance. 
Q. What are you hoping your legacy will be?

A. Luckily I have not reached the stage where one thinks about these kinds of silly things! I am trying to do good work and enjoy myself that's plenty.

Q. What are you reading at the moment?

A. I'm just finishing a book of short stories by Alice Munro, Too Much Happiness. I've also started The Apollonian Clockwork by Louis Andriessen and Elmer Schönberger - I've always wanted to read this book on Stravinsky's music.

Q. What current developments or trends do you perceive in new music?

A. In addition to lots of music using just intonation and microtones there is still a lot of interest in 'beatings' and various psychoacoustic effects. I am as curious about these trends as about the more 'maximalist' music of Richard Ayres, Jon Rose and others. It's also fantastic to see so many unexpected people writing orchestral and ensemble works - George Lewis, for example, whose exciting new orchestral work for BBC Scottish [Symphony Orchestra] I premiered this February. I am also noticing that the straight academic composers acknowledge more and more improvisers and other music outside their usual interests. This is crucial as it will hopefully give new energy to the whole scene: what's important is to keep a connection between high and low culture, and to expose the weakness of both, if need be; challenging the perceived ideas of what music should be and making sure that critical thought and real discussions are part of new music every day.

Q. Is there a project you are dreaming about creating?

A. I would love to have a touring big band of new music composers/ performers, with a tour bus and gigs every night. And I am dreaming of a location where musicians and artists can meet every year and explore new collaborations over a few weeks. A kind of Tectonics summer camp ...

Q. Is the future bright for new music?

A. Past, present and future are all bright actually! There is so much fantastic stuff being performed and composed today. There is no shortage of it. I also see many new collaborations between composers, performers, improvisers and audience that will take things further in a big way. Hopefully promoters and orchestras will be able to take the lead on this and open the door to it all. It's quite interesting how much of the most thrilling music now happens in small venues, with chamber and solo repertoire etc. This will still be where most experimentation will happen and where the most fun gigs will occur, but it's definitely possible to expand it and bring in a bigger audience - this is what Tectonics is partly about. I have been lucky to work with some amazing pioneers of new music (people like Alvin Lucier, Christian Wolff etc.) as well as the younger generation, and it has been a pleasure and a privilege to engage more deeply with them and their music. 